\title{
Monazite ID-TIMS U-Pb geochronology in the LAGIR laboratory, Rio de Janeiro State University: protocols and first applications to the assembly of Gondwana supercontinent in SE-Brazil
}

\author{
CARLA C.A. NETO ${ }^{1 *}$, CLAUDiO M. VALERIANO ${ }^{{ }^{*}}$, CLAUDiA R. PASSARELLI ${ }^{2}$, \\ MONICA HEILBRON ${ }^{1 *}$ and MARCELA LOBATO ${ }^{3 * *}$ \\ ${ }^{1}$ Universidade do Estado do Rio de Janeiro/ UERJ, Faculdade de Geologia, Laboratório de Geocronologia e Isótopos \\ Radiogênicos, Rua São Francisco Xavier, 524/4006-A, Maracanã, 20559-900 Rio de Janeiro, RJ, Brasil \\ ${ }^{2}$ Universidade de São Paulo/ USP, Instituto de Geociências, Rua do Lago 562, Butantã, 05508-080 São Paulo, SP, Brasil \\ ${ }^{3}$ Programa de Pós-Graduação em Análise de Bacias e Faixas Móveis, Universidade do Estado do Rio de Janeiro/ UERJ, \\ Faculdade de Geologia, Laboratório de Geocronologia e Isótopos Radiogênicos, \\ Rua São Francisco Xavier, 524/4006-A, Maracanã, 20559-900 Rio de Janeiro, RJ, Brasil.
}

Manuscript received on November 28, 2012; accepted for publication on September 9, 2013

\begin{abstract}
The chemical and spectrometric procedures of the U-Pb geochronology method on monazites, recently installed in the LAGIR laboratory, are described in detail. In addition, preliminary results on monazite samples from the Brasília and Ribeira belts are reported and discussed in the context of the regional geology. Several experiments for calibration of ion exchange chromatographic columns with the AG-1x8 resin, were performed with $\mathrm{HCl}$, using dissolved natural monazite samples. The $\mathrm{Pb}$ blanks of reagents are $\sim 0.5 \mathrm{pg} / \mathrm{g}$ in acids and $\sim 1 \mathrm{pg} / \mathrm{g}$ in $\mathrm{H}_{2} \mathrm{O}$. The total $\mathrm{Pb}$ blanks in chemical procedures were below $22 \mathrm{pg}$. Preliminary results are presented from three case studies related to Brasiliano orogenic belts of SE-Brazil, which correlate very well with previous age determinations from literature: two sub-concordant grains from an Araxá Group quartzite (southern Brasília belt) define a concordia age of $602.6 \pm 1.4 \mathrm{Ma}$; a $-0.8 \%$ discordant grain from a quartzite of the São Fidelis Group (Costeiro Domain, central Ribeira belt) yielded a concordia age of $535.3 \pm 2.4 \mathrm{Ma}$; two $0.4 \%$ and $1.3 \%$ discordant monazite grains from the post-collisional Itaoca Granite (Costeiro Domain, central Ribeira belt) define a concordia age of $476.4 \pm 1.8 \mathrm{Ma}$.
\end{abstract}

Key words: Gondwana, Brasiliano, isotope dilution mass spectrometry, U-Pb, monazite.

\section{INTRODUCTION}

The production of $\mathrm{U}-\mathrm{Pb}$ geochronology data during the last decade has experienced enormous growth with advances in instrumental diversity and precision. This is particularly true for Brazil, with the

\footnotetext{
Correspondence to: Carla Cristine Aguiar Neto

E-mail: neto.carla@hotmail.com

* Bolsista/ CNPq

** Bolsista/ CAPES
}

introduction of modern instrumentation in several universities, among which are LA-ICPMS (Buhn et al. 2009, Chemale Jr et al. 2012) and SHRIMP (Sato et al. 2008b) with configuration for U-Pb geochronology, and Electron Probe applied for the Th-U-Pb chemical method of age calculation (Vlach 2010).

Also a worldwide phenomenon is the lesser use of ID-TIMS, which may in simple terms be explained by the cost and work intensive nature of 
this method. Another feature is the non-renewable supply of the ${ }^{205} \mathrm{~Pb}$ isotopic tracer, only produced once (Parrish and Krogh 1987), since then split among laboratories worldwide. Furthermore, the compositional and isotopic heterogeneity, so often present in monazite crystals, is a potential source for problematic age results (Hawkins and Bowring 1997, Foster et al. 2002).

However, in spite of all the disadvantages, the ID-TIMS method occupies important analytical niches (Basei et al. 1995, Passarelli et al. 2009), owing to relatively higher precision in measurement of isotopic ratios, resulting in better age resolution. Furthermore, contrary to LA-ICPMS and SHRIMP, the ID-TIMS method does not require using standard monazite crystals for calculating mass fractionation and other instrumental bias. Good standard monazite crystals are rarely found in nature because they have to be isotopically homogeneous and yielding concordant $\mathrm{U}-\mathrm{Pb}$ ages, but also large enough to be split and distributed. In addition, they have to be calibrated isotopically with an independent tool, of which the best is ID-TIMS.

This article describes the U-Pb ID-TIMS analytical protocols recently installed by Neto et al. (2012) in the LAGIR - Laboratory of Geochronology and Radiogenic Isotopes of the Rio de Janeiro State University (UERJ).

The chemical separation of $\mathrm{Pb}$ and $\mathrm{U}$ is mostly adapted from traditional protocols at the GEOTOPUQAM in Montréal (Valeriano et al. 2004) and at the CPGeo-USP in São Paulo (Passarelli et al. 2009). The main chemical procedures in the LAGIR lab (Valeriano et al. 2003) are performed within four separate clean rooms (for purification of reagents, chemical extraction and sample weighing) doted with HEPA air filtering and positive air pressure. The instrumental strategy for the measurement of isotopic ratios of $\mathrm{Pb}$ and U with the TRITON mass spectrometer at LAGIR, are also described in detail.
Geologically significant results are presented from metamorphic and igneous rock samples collected in the Ribeira and Brasília Neoproterozoic orogenic belts of southeast Brazil. These new monazite $\mathrm{U}-\mathrm{Pb}$ ages are discussed in the context of the Neoproterozoic to Eo-Paleozoic assemblage of Gondwana supercontinent.

Monazite U-PB GEOCHRONOLOGY

The widespread occurrence in the Earth's crust and some intrinsic properties make monazite promising for U-Pb systematics (Parrish 1990). Monazite crystallizes in a wide variety of igneous rocks and in several progressive metamorphic reactions of medium- to high-grade. It is also very common as a detrital heavy mineral in clastic sedimentary rocks and their low grade metamorphic by-products (Deer et al. 1966)

Intrinsic properties of this mineral also help to define it as a quality geochronometer. It is a light rare earth phosphate easily soluble in $\mathrm{HCl}$. High contents of $U(282-13730 \mathrm{ppm})$ and $\mathrm{Th}(\sim 60000 \mathrm{ppm})$ in monazite greatly reduce the importance in age calculations. With blocking temperature of $\sim 700^{\circ} \mathrm{C}$ for $\mathrm{Pb}$, monazite is relatively resistant to $\mathrm{Pb}$ loss in low-temperature processes. Low diffusion rates allow for the preservation of growth and replacement compositional/isotopic domains, potentially yielding a detailed record of complex geological processes (Heaman and Parrish 1990, Dickin 1995).

$\mathrm{U}-\mathrm{Pb}$ analyses of monazite are commonly carried out using TIMS, SHRIMP, Laser AblationICPMS. Microprobe geochronology also yields detailed information on sub-grain age domains based on the Th-U-Pb system (Williams et al. 2007). TIMS analyses may involve whole single grains or sub-domains that can be obtained either mechanically by cutting/micro-drilling (Hawkins and Bowring 1997), or chemically using partial solution (Sato et al. 2008a).

However, monazite may pose several specific difficulties for the U-Pb method. As with other 
minerals, mixed ages may result from grains with internal chemical/isotopic domains, typically complex in monazite. In these cases, spatial resolution is pursued by selective spot sampling, such as in SHRIMP, LA-ICPMS and electron microprobe. In TIMS, air abrasion, micro-drilling and leaching techniques are common strategies for the reduction of sampling domains.

Another problem that may arise during mass spectrometry is a high ${ }^{208} \mathrm{~Pb}$ peak with a wide "tail" that may overlap the adjacent and much lower ${ }^{207} \mathrm{~Pb}$ peak. This can be overcome by keeping the ${ }^{208} \mathrm{~Pb}$ signal low enough, through loading small amounts of $\mathrm{Pb}$ on filament. Reverse age discordance is another common problem in monazite (Heaman and Parrish 1990), not only in the young $(<200 \mathrm{Ma})$ ones, in which there may be excess thorogenic ${ }^{206} \mathrm{~Pb}$, but also in much older samples, requiring explanation by other factors, such as fluid/mineral interactions.

\section{MATERIALS AND METHODS}

\section{Chemical Protocols AND Sub-Routines}

In this section the protocols installed are described in detail. The installation and maintenance of the $\mathrm{U}-\mathrm{Pb}$ geochronology using TIMS depends on parallel sub-routines not directly involved with the analysis of a specific sample (Figure 1), such as cleaning of reagents and vessels, determination of analytical blanks and calibration of ion exchange columns for $\mathrm{Pb}$ and $\mathrm{U}$ extraction. Other procedures related to mass spectrometry are also described below.

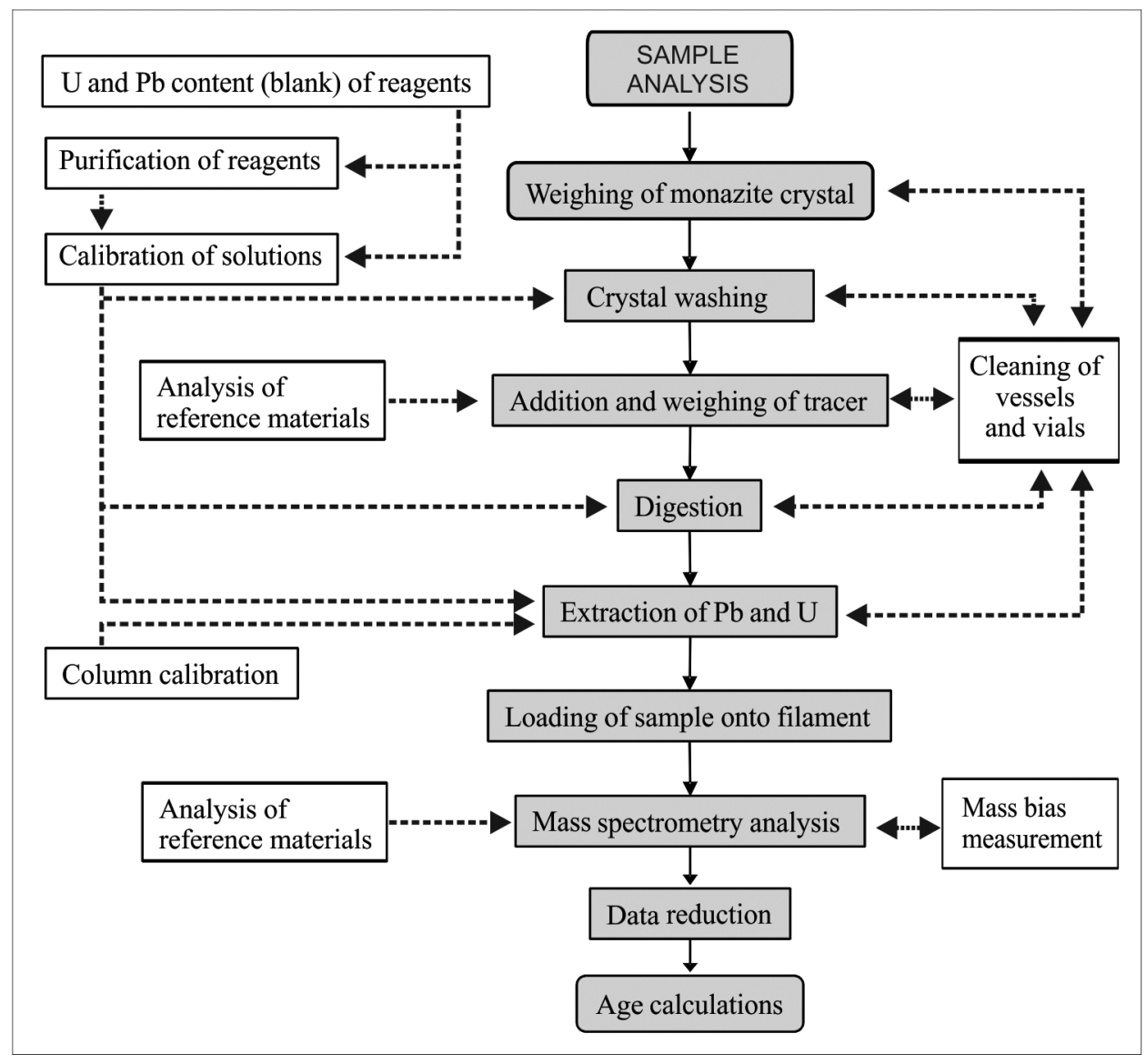

Figure 1 - Laboratory procedures in U-Pb ID-TIMS geochronology. White boxes display side procedures not directly involved in sample analysis (grey boxes). 
All vessels and bottles used in the U-Pb method are made of Teflon. Before use they are repeatedly cleaned on hot plate following three alternate cycles of $\mathrm{H}_{2} \mathrm{O}$ and $\mathrm{HCl} 6 \mathrm{M}$ at $90^{\circ} \mathrm{C}$ for 1 day each.

\section{Purification and determination of $\mathrm{Pb}$ content (blanks) of reagents}

Except for $\mathrm{H}_{3} \mathrm{PO}_{4}$, which is bought supra-pure, the $\mathrm{HCl}$ and $\mathrm{HNO}_{3}$ solutions are distilled in quartz and Teflon sub-boiling distillers. Purification of water involves particle separation using $5 \mu \mathrm{m}, 3 \mu \mathrm{m}$ and $1 \mu \mathrm{m}$ filters, then de-ionization with a Millipore ${ }^{\circledR}$ RiOs-5, and further purification with a Millipore Milli-Q Academic ${ }^{\circledR}$ system. In order to minimize contamination of reagents during the chemical procedures, all water, acid solution, resin suspension and isotopic tracer are stored in Teflon bottles and dispensed in drops from a capillary Teflon tube of 0.5 $\mathrm{mm}$ internal diameter passing through the perforated cap, yielding drops of $10 \mu \mathrm{L}$ volume.

The reported $\mathrm{Pb}$ content ("blanks") of reagents expresses the average of three measurements performed according to the following procedure: a) weighing of a clean $7 \mathrm{~mL}$ beaker; b) rinsing of beaker with the reagent; c) filling the beaker with the reagent and weight; e) adding $10 \mu \mathrm{L}$ of the ${ }^{208} \mathrm{~Pb}$ tracer and weight; g) adding $5 \mu \mathrm{L}$ of $\mathrm{H}_{3} \mathrm{PO}_{4} 0.25 \mathrm{~N}$; and $\mathrm{h}$ ) evaporation on hot plate until the formation of a droplet.

The samples are then loaded on double $\mathrm{Re}$ filament for measurement of ${ }^{206} \mathrm{~Pb} /{ }^{208} \mathrm{~Pb}$ isotopic ratios. The $\mathrm{Pb}$ content shown by $\mathrm{B}$ is expressed as

$$
B=\left[\frac{\left({ }^{206} \mathrm{~Pb} /{ }^{208} \mathrm{~Pb}\right)_{t r}-\left({ }^{206} \mathrm{~Pb} /{ }^{208} \mathrm{~Pb}\right)_{m}}{\left({ }^{206} \mathrm{~Pb} /{ }^{208} \mathrm{~Pb}\right)_{m}-\left({ }^{206} \mathrm{~Pb} /{ }^{208} \mathrm{~Pb}\right)_{\text {nat }}}\right] x\left[\frac{\left[{ }^{208} \mathrm{~Pb}\right]_{t r} x\left[\%^{208} \mathrm{~Pb}\right]_{t r} x P A_{P b n a f} x P_{t r}}{\left({ }^{208} \mathrm{~Pb}\right)_{\text {nat }} x P A_{P b t r} x P_{s}}\right],
$$

where:

$\mathrm{B}=\mathrm{Pb}$ content in $\mathrm{ng} / \mathrm{g}$;

$\left({ }^{206} \mathrm{~Pb} /{ }^{208} \mathrm{~Pb}\right)_{\mathrm{tr}}=$ isotopic ratio of tracer;

$\left({ }^{206} \mathrm{~Pb} /{ }^{208} \mathrm{~Pb}\right)_{\mathrm{m}}=$ isotopic ratio of sample;

$\left({ }^{206} \mathrm{~Pb} /{ }^{208} \mathrm{~Pb}\right)_{\text {nat }}=$ isotopic ration of common lead;

$\left[{ }^{208} \mathrm{~Pb}\right]_{\mathrm{tr}}=$ concentration in nanomol $/ \mathrm{g}$ in tracer;

$\left[\%{ }^{208} \mathrm{~Pb}\right]_{\mathrm{tr}}=$ abundance in tracer;

$\mathrm{PA}_{\mathrm{Pb} \text { nat }}=$ atom weight of common $\mathrm{Pb}$;

$\left({ }^{208} \mathrm{~Pb}\right)_{\text {nat }}=$ natural abundance;

$\mathrm{PA}_{\mathrm{Pb} \text { tr }}=$ atom weight of tracer;

$\mathrm{P}_{\mathrm{tr}}=$ tracer volume $(\mathrm{mL})$;

$\mathrm{P}_{\mathrm{s}}=$ sample weight $(\mathrm{g})$.
The obtained blanks are: $0.4 \mathrm{pg} / \mathrm{g}$ for $\mathrm{HNO}_{3}$ $6 \mathrm{M}, 0.2 \mathrm{pg} / \mathrm{g}$ for $\mathrm{HCl} 6 \mathrm{M}, 7.0 \mathrm{pg} / \mathrm{g}$ for $\mathrm{H}_{2} \mathrm{O}$ from the de-ionizer and $1.1 \mathrm{pg} / \mathrm{g}$ for $\mathrm{H}_{2} \mathrm{O}$ from Milli-Q.

\section{Weighing, cleaning and digestion of monazite} grains

After manual selection a monazite grain, which ideally should be homogeneous and devoid of inclusions or fractures, its weight is measured with $10-6 \mathrm{~g}$ precision before transfer to a $10 \mathrm{~mL}$ glass beaker for cleaning procedure. All care must be taken not to lose the grain when discarding the cleaning reagents:

\section{Procedure}

Times repeated

Rinse with acetone under ultra-sound for 1 minute and discard

1

Rinse with $\mathrm{H}_{2} \mathrm{O}$ under ultra-sound for 1 minute and discard

3

Add $\mathrm{HNO}_{3} 3 \mathrm{~N}$, leave for 10 minutes on hot plate $\left(90^{\circ} \mathrm{C}\right)$; let cool in ultra-sound for 1 minute and discard

Rinse with $\mathrm{H}_{2} \mathrm{O}$ under ultra-sound for 1 minute and discard

Rinse with acetone under ultra-sound for 1 minute and discard 
After cleaning, digestion of the crystal is done in a $3 \mathrm{~mL}$ Teflon beaker on hot plate at $\sim 150^{\circ} \mathrm{C}$ for 3 days, with $10 \mu \mathrm{L} \mathrm{HCl} 6 \mathrm{M}$ and a proportional mass of a mixed ${ }^{235} \mathrm{~Pb}-{ }^{205} \mathrm{~Pb}$ tracer solution (described below). The solution is left to evaporate on hot plate at $\sim 90^{\circ} \mathrm{C}$ ) until the formation of a droplet.

In order to feed the ion exchange chromatographic column for extraction of $\mathrm{Pb}$ and $\mathrm{U}$, the sample is conditioned with 10 drops $(100 \mu \mathrm{L})$ of $\mathrm{HCl}(3 \mathrm{M})$.

\section{Calibration of ion exchange micro-columns for extraction of $\mathrm{Pb}$ and $\mathrm{U}$}

The separation of $\mathrm{U}$ and $\mathrm{Pb}$ follows the classic method using the anion resin $\mathrm{AG}-1 \mathrm{x} 8$ and $\mathrm{HCl}$ e $\mathrm{H}_{2} \mathrm{O}$ for $\mathrm{Pb}$ and $\mathrm{U}$ elution, respectively (Parrish 1990).

The process of calibration of the ion exchange micro-columns consists of the establishment of what volumes of solution passing through the resin will be collected for $\mathrm{Pb}$ and $\mathrm{U}$. The monazite grains used to prepare a calibration solution were picked from a quartzite sample (1042, see results below) that had other monazite grains previously analyzed by ID-TIMS (Valeriano et al. 2004).

The micro-columns used in LAGIR were handcrafted from a teflon tube by hot air shrinking at the GEOTOP-UQAM (Montréal, Canada), resulting in an internal diameter of $1.8 \mathrm{~mm}$ and height of 11 $\mathrm{mm}$, with a small cup above the resin tube.

Once filled with the resin, the column is cleaned by washing three times with alternated $\mathrm{HCl} 6 \mathrm{M}$ and $\mathrm{H}_{2} \mathrm{O}$. The resin is then conditioned with 16 drops $(160 \mu \mathrm{L})$ of $\mathrm{HCl} 3 \mathrm{~N}$. The sample is conditioned by adding to its beaker 10 drops $(100 \mu \mathrm{L})$ of $\mathrm{HCl} 3 \mathrm{M}$, before transfer to the column. In order to force the sample solution down the resin column, $1+1+1+10$ drops $(130 \mu \mathrm{L})$ of $\mathrm{HCl} 3 \mathrm{M}$ are successively added.

In order to determine the best volume aliquots for extraction of $\mathrm{Pb}$ and $\mathrm{U}$, three calibration curves of relative concentration of $\mathrm{Pb}$ and $\mathrm{U}$ versus volume aliquot were constructed, following the procedure detailed below:

\begin{tabular}{|c|c|c|}
\hline TASK & REAGENT & VOLUME \\
\hline Sample transfer & \multicolumn{2}{|c|}{ Place beaker for aliquot $\mathbf{0}$} \\
\hline \multirow{5}{*}{ Elution of REE } & $\mathrm{HCl} 3 \mathrm{M}$ & 1 drop $(10 \mu \mathrm{L})(3$ times $)$ \\
\hline & $\mathrm{HCl} 3 \mathrm{M}$ & 1 drop $(10 \mu \mathrm{L})$ \\
\hline & $\mathrm{HCl} 3 \mathrm{M}$ & 1 drop $(10 \mu \mathrm{L})$ \\
\hline & \multicolumn{2}{|c|}{ Place beaker for aliquot 1} \\
\hline & $\mathrm{HCl} 3 \mathrm{M}$ - aliquot 1 & 10 drops $(100 \mu \mathrm{L})$ \\
\hline Collection of $\mathrm{Pb}$ & $\mathrm{HCl} 6 \mathrm{M}$ - aliquots 2 to 5 & 4 drops each $(40 \mu \mathrm{L})$ \\
\hline Collection of $\mathbf{U}$ & $\mathrm{H}_{2} \mathrm{O}-$ aliquots 6 to 14 & 4 drops each $(40 \mu \mathrm{L})$ \\
\hline
\end{tabular}

The analytical signal of $\mathrm{U}$ and $\mathrm{Pb}$ in each aliquot, expressed in counts per second (cps), was measured by TIMS and ICPMS to be used as a proxy for the concentration of these elements in the solution after passing through the resin.

Two of the calibration experiments were carried out with the TIMS, loading the sample onto a double filament mount. The intensity of ${ }^{208} \mathrm{~Pb}$ was measured first with the sample filament at $1250^{\circ} \mathrm{C}$ (ionization filament off). For measurement of ${ }^{235} \mathrm{U}$ intensity, the sample filament and the ionization filament are set with currents of $2.4 \mathrm{~A}$ and $4.5 \mathrm{~A}$ respectively (Figure 2a). A third calibration curve was constructed using signals measured by an ICPMS (Figure 2b). The intensity for 15 rare earth elements and isotopes of $\mathrm{U}$ and $\mathrm{Pb}$ in this experiment is below: For both TIMS and ICPMS measurements, two columns were used.

Based on these calibration experiments, two different procedures were tested: in the first one 

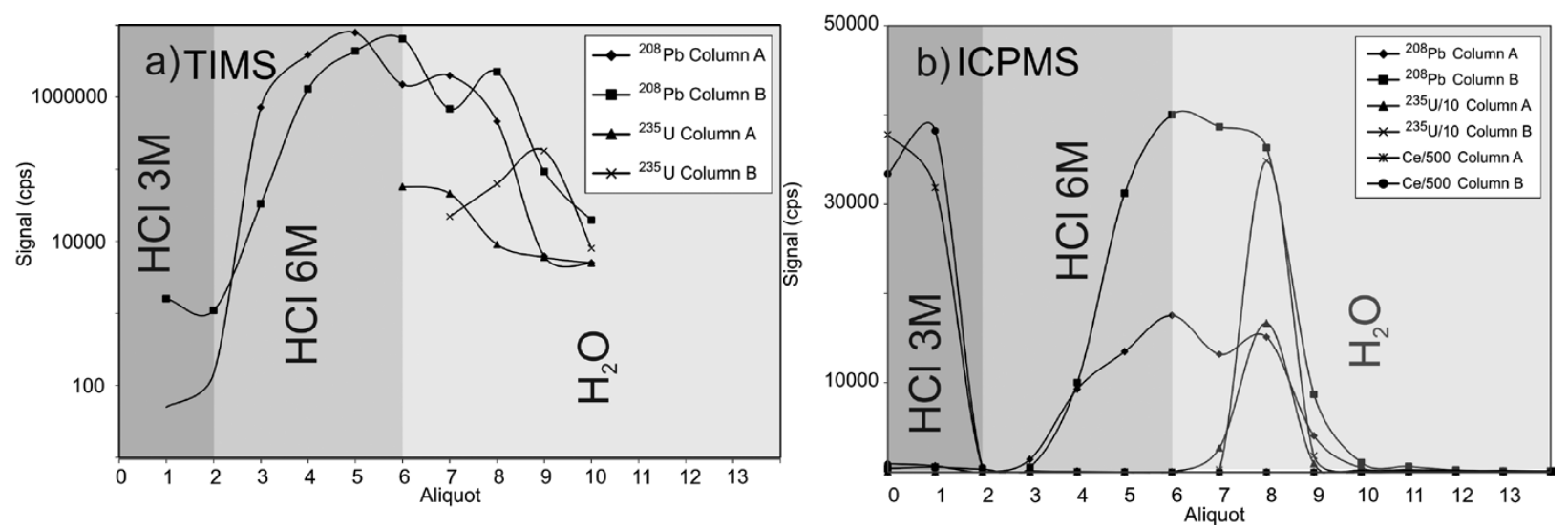

Figure 2 - Diagrams of signal intensity (cps) versus volume of solution through resin column, measured by using TIMS (a) and ICPMS (b), used in the chromatographic separation of $\mathrm{Pb}$ and $\mathrm{U}$.

(Series U-Pb 01), $\mathrm{Pb}$ was collected from aliquot 02 on, and in the other one (Series $\mathrm{U}-\mathrm{Pb} 02), \mathrm{Pb}$ was collected from aliquot 04 on, which was the preferred one because it avoided collecting high amounts of Ce, observed in Figure 2b. The adopted protocol is presented below:

\begin{tabular}{|c|c|c|}
\hline TASK & REAGENT & VOLUME \\
\hline \multirow{3}{*}{ CLEANING OF COLUMN } & $\mathrm{HCl} 6 \mathrm{M} / \mathrm{H}_{2} 0 \mathrm{MQ}$ & Fill column and cup \\
\hline & $\mathrm{HCl} 6 \mathrm{M} / \mathrm{H}_{2} 0 \mathrm{MQ}$ & Fill column and cup \\
\hline & $\mathrm{HCl} 6 \mathrm{M} / \mathrm{H}_{2} \mathrm{OMQ}$ & Fill column and cup \\
\hline \multirow{3}{*}{ CLEANING OF RESIN } & $\mathrm{HCl} 6 \mathrm{M} / \mathrm{H}_{2} 0 \mathrm{MQ}$ & Fill column and cup \\
\hline & $\mathrm{HCl} 6 \mathrm{M} / \mathrm{H}_{2} \mathrm{OMQ}$ & Fill column and cup \\
\hline & $\mathrm{HCl} 6 \mathrm{M} / \mathrm{H}_{2} 0 \mathrm{MQ}$ & Fill column and cup \\
\hline RESIN CONDITIONING & $\mathrm{HCl} 3 \mathrm{M}$ & 16 drops $(160 \mu \mathrm{L})$ \\
\hline SAMPLE CONDITIONING & $\mathrm{HCl} 3 \mathrm{M}$ & 10 drops $(100 \mu \mathrm{L})$ \\
\hline SAMPLE TRANSFER & \multicolumn{2}{|c|}{ Load sample previously conditioned with $\mathrm{HCl} 3 \mathrm{M}$} \\
\hline \multirow{5}{*}{ ELUTION OF REE } & $\mathrm{HCl} 3 \mathrm{M}$ & 1 drop $(10 \mu \mathrm{L})$ \\
\hline & $\mathrm{HCl} 3 \mathrm{M}$ & 1 drop $(10 \mu \mathrm{L})$ \\
\hline & $\mathrm{HCl} 3 \mathrm{M}$ & 1 drop $(10 \mu \mathrm{L})$ \\
\hline & $\mathrm{HCl} 3 \mathrm{M}$ & 10 drops $(100 \mu \mathrm{L})$ \\
\hline & \multicolumn{2}{|c|}{ Change to clean vial } \\
\hline Elution of $\mathrm{Pb}$ & $\mathrm{HCl} 6 \mathrm{M}$ & 16 drops $(160 \mu \mathrm{L})$ \\
\hline \multirow[t]{2}{*}{ Elution of $U$} & H2O MQ & 28 drops $(280 \mu \mathrm{L})$ \\
\hline & $\mathrm{H}_{3} \mathrm{PO}_{4} 0.25 \mathrm{~N}$ & $1-2$ drops $(10-20 \mu \mathrm{L})$ \\
\hline
\end{tabular}

THERMAL IONIZATION MASS SPECTROMETRY - TIMS

\section{Measurement of $\mathrm{Pb}$ and $U$ isotope composition of spiked samples}

The measurement of isotope ratios in LAGIR is performed with the TRITON thermal ionization multicollector mass spectrometer. A minimum of 100 cycles for recording the $\mathrm{Pb}$ and $\mathrm{U}$ isotope is measured.
Lead and Uranium are loaded onto the same Rhenium filament, which must be previously degassed by means of current heating under vacuum. A mixture of silica gel $(2 \mu \mathrm{L}), \mathrm{H}_{3} \mathrm{PO}_{4} 1 \mathrm{~N}$ $(1 \mu \mathrm{L})$ and the sample can be blended together and transferred to the filament or they can be loaded successively. The loaded filament is then dried out with a current of $1.5 \mathrm{~A}$ until formation and cessation 
of fumes. Final drying is reached slowly elevating the current to $\sim 2.5 \mathrm{~A}$ until filament starts to glow during $\sim 3$ seconds.

In order to analyze $U$ in metallic form, a double filament assembly was used for this element only. Thus, $\mathrm{Pb}$ isotopes are measured first in single filament mode by keeping the ionization filament off. The sample filament was set from $1250^{\circ} \mathrm{C}$ to $1350^{\circ} \mathrm{C}$, corresponding to currents of $\sim 2.5 \mathrm{~A}-2.8 \mathrm{~A}$. The isotope ratios are acquired in static mode, with ${ }^{204} \mathrm{~Pb}$ measured with an ion-counter located at the low mass side, and the other ${ }^{205} \mathrm{~Pb}$ (tracer), ${ }^{206} \mathrm{~Pb}$, ${ }^{207} \mathrm{~Pb},{ }^{208} \mathrm{~Pb}$ masses with Faraday cups.

Isotopic measurements of $\mathrm{U}$ are carried out with a current of $4.0 \mathrm{~A}$ to $4.2 \mathrm{~A}$ in the ionization filament and of $2.0 \mathrm{~A}$ in the evaporation (sample) filament. The ${ }^{235} \mathrm{U} /{ }^{238} \mathrm{U}$ isotope ratio is measured by peak jumping using a Secondary Electron Multiplier (SEM) collector.

\section{Mass fractionation and isotopic characterization} of blanks and tracer

Before the measured isotope ratios are used for the calculation of ages, they must be corrected for instrumental mass fractionation and for the $U$ and $\mathrm{Pb}$ contents and isotope spectrum in the tracer used and in the laboratory blanks.

The determination of mass fractionation of $\mathrm{Pb}$ and $\mathrm{U}$ is calculated from repeated measurement of NBS-981 and U-500 reference materials under the same analytical conditions (vacuum, filament temperature, sample amount loaded) as for the measured samples. The average mass fractionation during the experiments was $0.08+/-0.05 \%$ a.m.u. (atomic mass unit) for $\mathrm{Pb}$ and $0.43+/-0.05 \%$ a.m.u. for $\mathrm{U}$.

The mixed ${ }^{205} \mathrm{~Pb}-{ }^{235} \mathrm{U}$ tracer used was donated by the Laboratory of Geochronology of the University of Brasília (UnB), with the following compositional and isotopic characteristics:

\begin{tabular}{ccc|ccccc}
\hline \multicolumn{2}{c|}{ Concentrations (\% mol/g) } & \multicolumn{5}{|c}{ Isotope ratios } \\
\hline$[205]$ & {$[235]$} & {$[230]$} & $206 / 205$ & $206 / 204$ & $206 / 207$ & $206 / 208$ & $238 / 235$ \\
\hline $4.66 \mathrm{E}-11$ & $4.21 \mathrm{E}-09$ & $1.00 \mathrm{E}-09$ & 0.00028 & 6.666 & 1.1628 & 0.4311 & 0.00535 \\
\hline
\end{tabular}

The analytical blank comprises the amount and isotope composition of all $\mathrm{Pb}$ and $\mathrm{U}$ introduced to the analyzed sample during the whole laboratory procedure, from cleaning of monazite crystal until filament loading. The $\mathrm{Pb}$ blanks are calculated with the formula:

$$
\text { Blank }=\left[\left({ }^{206} \mathrm{~Pb} /{ }^{205} \mathrm{~Pb}\right)_{m}-\left({ }^{206} \mathrm{~Pb} /{ }^{205} \mathrm{~Pb}\right)_{t r}\right] x\left[\left(\left[{ }^{205} \mathrm{~Pb}\right]_{t r} x W_{t r} x 4\right) x 1000\right]
$$

where:

${ }^{206} \mathrm{~Pb} /{ }^{205} \mathrm{~Pb}_{\mathrm{m}}=$ measured isotopic ratio in sample;

${ }^{206} \mathrm{~Pb} /{ }^{205} \mathrm{~Pb}_{\text {tr }}=$ measured isotopic ratio in tracer;

$\left[{ }^{205} \mathrm{~Pb}\right]_{\mathrm{tr}}={ }^{205} \mathrm{~Pb}$ concentration in tracer, expressed as nanomol $/ \mathrm{g}$;

$\mathrm{W}_{\mathrm{tr}}=$ tracer weight in grams.

The PBDAT (Ludwig 1993) software was used for corrections of measured ratios and for calculation of the ${ }^{206} \mathrm{~Pb} /{ }^{238} \mathrm{U},{ }^{207} \mathrm{~Pb} /{ }^{235} \mathrm{U}$ and ${ }^{207} \mathrm{~Pb} /{ }^{206} \mathrm{~Pb}$ ages and propagated errors. The ISOPLOT software (Ludwig 2003) was used for data representation in concordia diagrams and for calculation of concordia ages and upper/lower intercepts of discordia, and related statistics.
APplications to the ConteXt OF THE BRASILIANO

Tectonic Collage IN Southeast BRaziL

First results from three different case studies are presented below, followed by discussion of their geological significance in the context of previous specific or regional data. The monazites analyzed were picked samples belonging to different tectonic contexts: a) a quartzite sample from the southern Brasília belt, of which monazites had previously been dated by ID-TIMS U-Pb; b) a quartzite sample from the central Ribeira belt; and c) a post-collisional leucogranite that intruded the latter belt. 
The Brasília and Ribeira orogenic belts are first order tectonic features in southeast Brazil and are distributed around the southernmost extents of the São Francisco craton (Figure 3). The orogenic processes involved in these Brasiliano-Panafrican belts and intervening cratonic blocks evolved in the context of the assembly of supercontinent Gondwana (Cordani et al. 2003, Fuck et al. 2008). The long-lived supercontinent collage involved a diachronic succession of accretionary and collisional events during most of the Neoproterozoic, and started with the formation of the earliest magmatic arcs in the Tonian. Major continent and arc-collision events took place during the Cryogenian and Ediacaran. These were followed by a post-collisional transition phase during the Cambrian and Ordovician. The stability of platform conditions, with the installation of extensive intracratonic sag-type sedimentary basins was reached only during the Silurian.

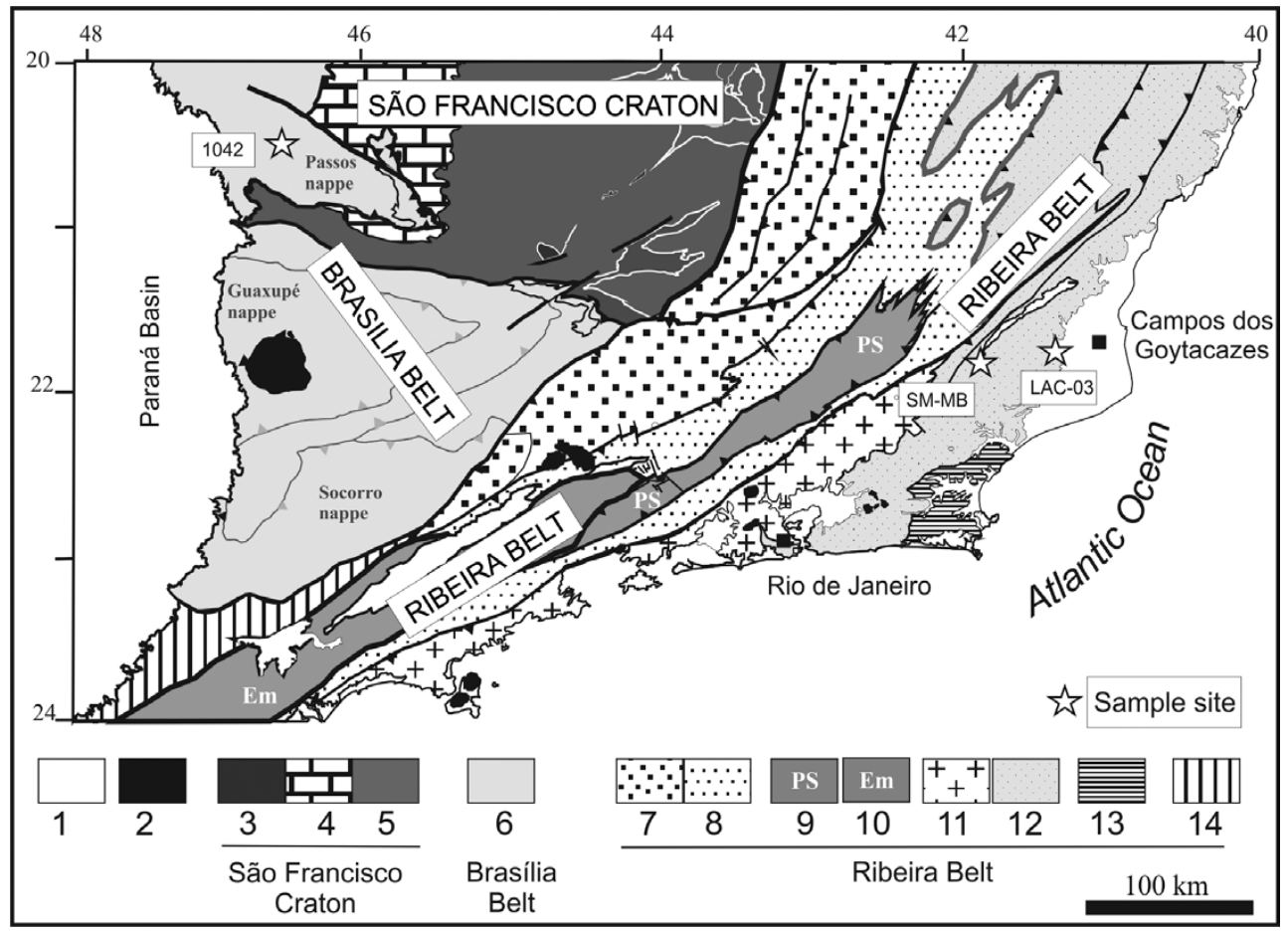

Figure 3 - Tectonic features of SE Brazil and location of studied samples (modified from Heilbron et al. 2008). Legend: 1- Phanerozoic cover; 2- Mesozoic-Paleogene alkaline intrusions. Units of São Francisco Craton: 3- Archean-Paleoproterozoic basement; 4- Bambuí Group; 5- Meso- Neoproterozoic cratonic cover. 6- Brasília belt. Tectonic domains of Ribeira belt: 7- Andrelândia; 8- Juiz de Fora; 9- Paraíba do Sul; 10- Embu; Oriental Terrane: 11- Rio Negro Magmatic Arc; 12- São Fidelis Group; 13- Cabo Frio Terrane; 14- Apiaí Terrane.

METAMORPHISM OF THE ARAXÁ GROUP IN THE PASSOS

NAPPE, SOUTHERN BRASÍLIA BELT

\section{Geologic context of the Southern Brasilia belt}

The southern Brasília belt (Dardenne 2000, Valeriano et al. 2008) comprises thrust stacking of metamorphic nappes over a foreland thrust- fold belt of low to medium grade metasedimentary rocks of the Neoproterozoic passive margin of western São Francisco paleocontinent. The thrust stacking was caused by the east-vergent accretion of terranes such as the southern portion of the Goiás Magmatic Arc and the Paranapanema craton. The latter block is located farther west, but presently 
is completely covered by the Phanerozoic Paraná basin (Mantovani and Brito Neves 2005).

Subduction of distal passive margin subjected the Araxá Group metasediments and associated mafic rocks to medium-high-pressure metamorphism at $\sim 640 \mathrm{Ma}$. Arc-continent collision and nappe exhumation took place between 620-605 Ma, indicated by $\mathrm{U}-\mathrm{Pb}$ ages on monazites (Valeriano et al. 2004). Cooling below $250-300^{\circ} \mathrm{C}$ took place at $\sim 600-580 \mathrm{Ma}$, as indicated by K-Ar ages of micas (Valeriano et al. 2000).

\section{Sample description, results and discussion}

Two first monazite grains were picked from sample 1042 (WGS 84 coordinates $20.500815^{\circ} \mathrm{S}$, $46.812173^{\circ} \mathrm{W}$ ), a quartzite from which monazites had previously been analyzed using ID-TIMS (Valeriano et al. 2004). The sample consists of a coarse-grained quartzite intercalated within paragneisses of the top units of the Araxá Group, in the Passos Nappe (SW Minas Gerais State), where metamorphic conditions reached the transition of amphibolite to granulite facies.

Grains 1042-B and 1042-I are respectively $-0.6 \%$ and $0.5 \%$ discordant, defining together a concordia age of $602.6 \pm 1.4 \mathrm{Ma}$ (Figure 4 ). This age is in accordance with $603.7 \pm 1.3 \mathrm{Ma}$, the concordia age of grain 1042-5 of Valeriano et al. (2004).

The other two more discordant grains, 1042-A and 1042-J, have ${ }^{207} \mathrm{~Pb} /{ }^{206} \mathrm{~Pb}$ ages respectively of $633 \pm 15 \mathrm{Ma}$ and $622 \pm 8 \mathrm{Ma}$, and behave more like grain 1042-3, of Valeriano et al. (2004), which is $1.1 \%$ discordant with age of $622 \pm 2 \mathrm{Ma}$.

EVOLUTION OF THE ORIENTAL TERRANE IN THE CENTRAL RIBEIRA BELT: METAMORPHISM OF THE SÃO FIDELIS GROUP Metasediments And Age of THE Post-Collisional

\section{ITAOCA GRANITE}

\section{Geologic context of central Ribeira belt}

The central Ribeira belt in southeast Brazil resulted from the convergence between the São Francisco/

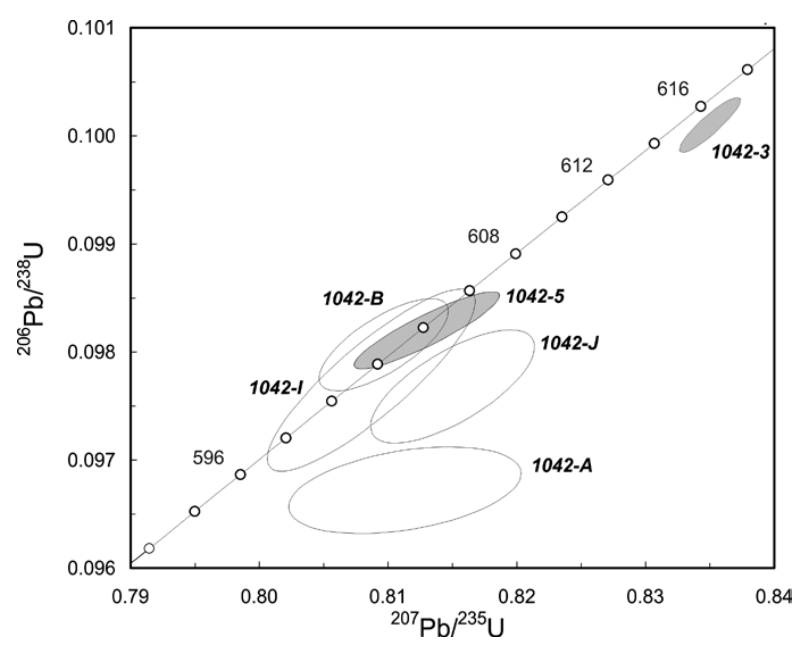

Figure 4 - Concordia diagram for monazites from Araxá Group quartzite sample in the Passos Nappe, Southern Brasília belt (sample 1042). Grey ellipses illustrate previous ID-TIMS results for the same sample (Valeriano et al. 2004).

Congo, Angola and minor lithospheric plates such as the Paraíba do Sul/Embú, Curitiba and Cabo Frio, during Neoproterozoic to Cambrian times (Heilbron et al. 2008).

The tectonic organization of the belt is defined by tectono-stratigraphic terranes showing imbrications towards NW onto the southernmost border of the former São Francisco paleocontinent (Occidental Terrane), each one with its particular range of metamorphic ages: the Paraíba do SulEmbú (620-600 Ma), the Oriental (605-560 Ma) and the Cabo Frio terranes (535- $510 \mathrm{Ma}$ ). The first two collision episodes were highly oblique resulting in partitioning of deformation between areas with a thrust-belt style separated by sub-vertical dextral shear zones. A final episode of tectonic collapse at ca. 510-480 Ma marks the transition to a stable platform in the Eo-Paleozoic (Machado et al. 1996, Heilbron et al. 2000, 2004, 2008, Schmitt et al. 2004).

The Oriental Terrane is the only tectonic unit containing magmatic arc related rocks, intruding metasedimentary units represented by paragneisses and associated quartzites and carbonatic rocks. These arc rocks have ages ranging from $790 \mathrm{Ma}$ to 610 Ma (Heilbron and Machado 2003, Tupinambá 
et al. 2000, 2011) that indicate towards a protracted oceanic subduction period that predates the above-mentioned collision episodes. The $\mathrm{Sr}$ and $\mathrm{Nd}$ isotopic data indicates a juvenile scenario that evolves towards cordilleran arc settings. The metasedimentary and arc units are intruded by generations of syn-, late- and post-collisional granitoid rocks.

São Fidelis group paragneisses and intercalated quartzites: sampling and results

The Costeiro Domain, one of the three thrustsheets that make up the Oriental Terrane, is largely represented by the São Fidelis Group, a metasedimentary unit of high metamorphic grade. It consists of a basal unit of kinzigitic paragneisses and a top unit of sillimanite garnet biotite paragneisses containing quartzite and calc-silicate intercalations (Heilbron 2012).

Three outcrops were sampled from a NE-trending unit of banded (sillimanite) garnet biotite paragneiss (sample SM-MB-02, coordinates $21.971890^{\circ} \mathrm{S}$, $42.152055^{\circ} \mathrm{W}$ ) with quartzite intercalations (samples SM-MB-09, coordinates $21.941585^{\circ} \mathrm{S}, 42.121331^{\circ} \mathrm{W}$ and SM-MB-15, coordinates $21.874732^{\circ} \mathrm{S}$, $42.058318^{\circ} \mathrm{W}$ ). The sampling sites are located nearby the São Sebastião do Alto village in the Serra do Mar, a mountain range that runs along northern State of Rio de Janeiro.

The quartzites are coarse grained and occur as discontinuous layers with thickness varying from centimetric to decametric, showing graded contacts with the enclosing pelitic to psammopelitic paragneisses. In more expressive strata, a conspicuous sedimentary layering is observed, with a wide range in contents of biotite, muscovite, feldspar and sillimanite.

The selected monazite grains display yellow to pale yellow color, are idiomorphic and transparent, free of inclusions or fractures. They were handpicked from heavy-mineral concentrates, with abundant zircon, ilmenite, rutile and apatite.
The monazite grain from quartzite sample SM-MB-15 is $-0.8 \%$ discordant at $535.3 \pm 2.4 \mathrm{Ma}$ (Figure 5), which is consistent with the accepted age for the M2 regional metamorphic event (Machado et al. 1996, Heilbron and Machado 2003), related to docking of the Cabo Frio terrane in Cambrian times (Schmitt et al. 2004). Monazite from quartzite sample SM-MB-09 is more discordant (4.6\%), but yielding a coinciding ${ }^{206} \mathrm{~Pb} /{ }^{238} \mathrm{U}$ age of $533 \mathrm{Ma}$. Sample SM-MB-02 from the paragneiss sample is $22 \%$ discordant with a ${ }^{206} \mathrm{~Pb} /{ }^{238} \mathrm{U}$ age of $553 \mathrm{Ma}$ that has no evident geologic significance.

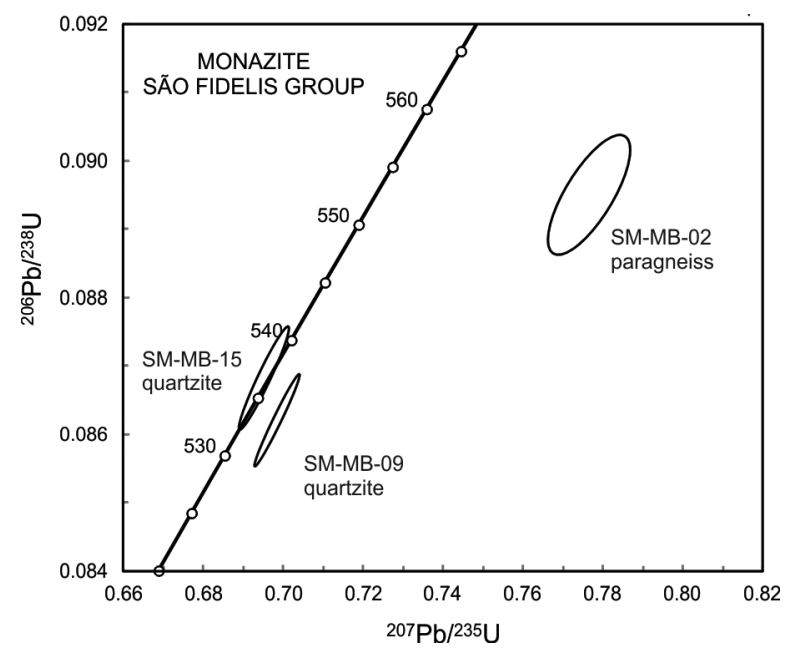

Figure 5 - Concordia diagram for monazites from São Fidelis Group samples. Grain SM-MB-15 is concordant at $535.3 \pm$ 2.4 Ma.

The post-collisional Itaoca Granite: sampling and results

The Itaoca granite is an intrusive body with $\sim 5 \mathrm{~km}$ diameter intruded within the São Fidelis Group paragneisses of the Oriental Terrane. It forms an outstanding rocky hill almost $400 \mathrm{~m}$ high located 14 $\mathrm{km}$ southwest of the Campos dos Goytacazes town.

A sample of the Itaoca Granite weighing $\sim 10 \mathrm{~kg}$ was collected at site LAC-03, a small quarry at coordinates $21.821143^{\circ} \mathrm{S}$ and $41.455348^{\circ} \mathrm{W}$. The outcrop is represented by the typical medium to coarse-grained porphyritic facies of leucocratic 
monzogranite, containing discoid biotite-rich enclaves oriented parallel to a conspicuous magmatic flow foliation.

Seven out of the eight analyzed monazites yielded Ordovician ${ }^{206} \mathrm{~Pb} /{ }^{238} \mathrm{U}$ ages between 412 $\mathrm{Ma}$ and $478 \mathrm{Ma}$, with discordance of up to $7 \%$ (Tables I and II).

Grains $\mathrm{H}$ and $\mathrm{L}$ are respectively $99.6 \%$ and 98.7\% concordant (Figure 6). Together, they define a concordia age of $476.4 \pm 1.8 \mathrm{Ma}$ interpreted as the best estimate for the crystallization of the Itaoca granite (Figure 6a). These two grains along with more discordant grains $\mathrm{T}$ and $\mathrm{N}$, define a discordia line with lower intercept of $475.6 \pm 4.3 \mathrm{Ma}$, in the inverse (Tera and Wasserburg 1972) diagram (Figure 6b).

Previous $\mathrm{U}-\mathrm{Pb}$ ages from a variety of other postcollisional granites of the states of Rio de Janeiro and Espirito Santo, reveal two main pulses of granite generation, at $\sim 511 \mathrm{Ma}$ and $\sim 485 \mathrm{Ma}$ (Valeriano et al. 2011). The reported age of $\sim 476 \mathrm{Ma}$ for the Itaoca Granite, is pertinent to the second pulse of postcollisional granites in central Ribeira belt.
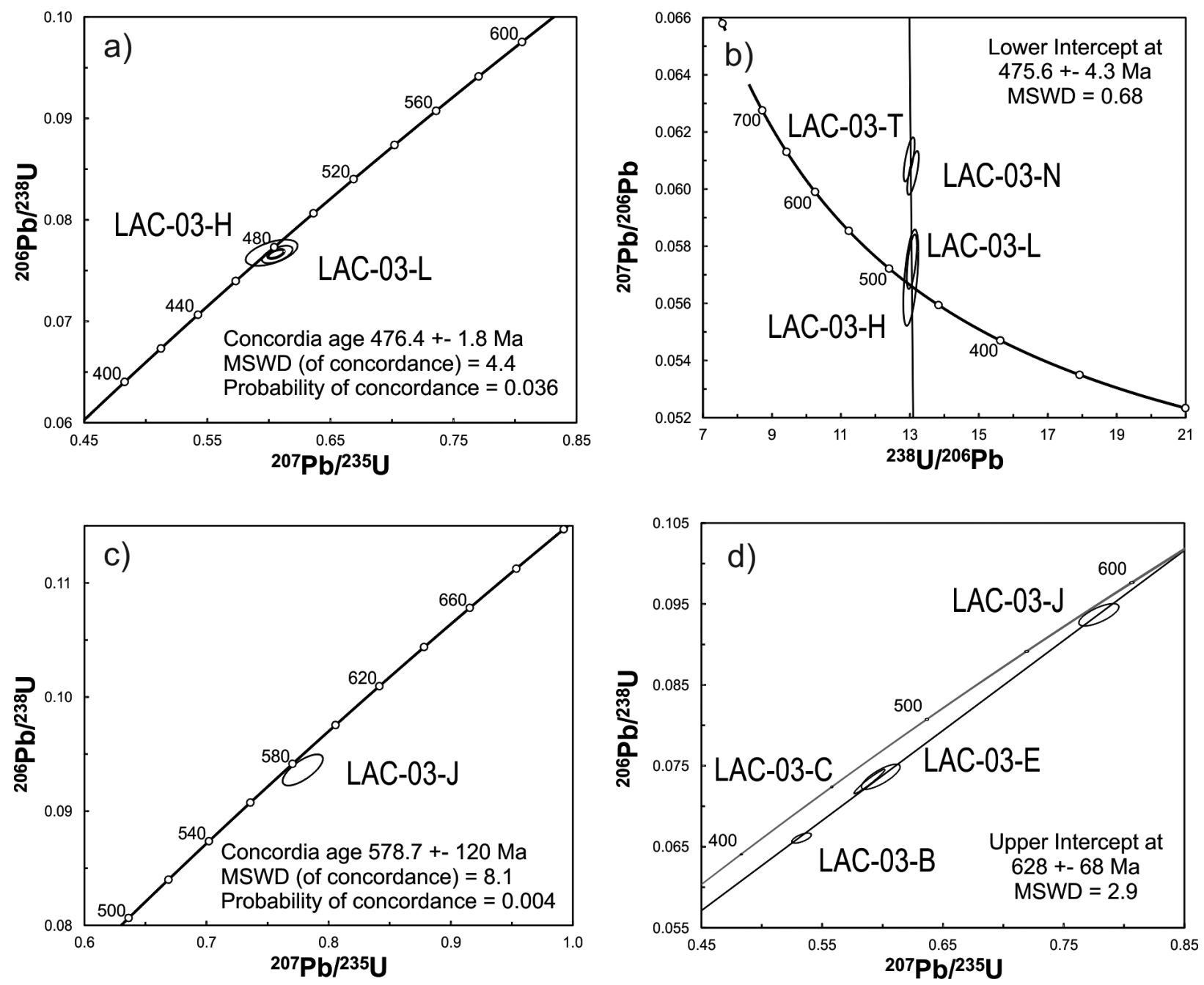

Figure 6 - Concordia diagrams for monazites from sample LAC-03 of the Itaoca Granite. a) Concordia age of $476.4 \pm 1.8 \mathrm{Ma}$ for grains $\mathrm{H}$ and $\mathrm{L}$, interpreted as the best estimate of crystallization; b) discordia line for grains $\mathrm{H}, \mathrm{L}, \mathrm{N}$ and $\mathrm{T}$ with lower intercept at $475.6 \pm 4.3 \mathrm{Ma}$; c) Concordia age of ca. $579 \mathrm{Ma}$ for grain $\mathrm{J}$; d) upper intercept for grains $\mathrm{B}$, E and J at ca $630 \mathrm{Ma}$ (see text for discussion). 


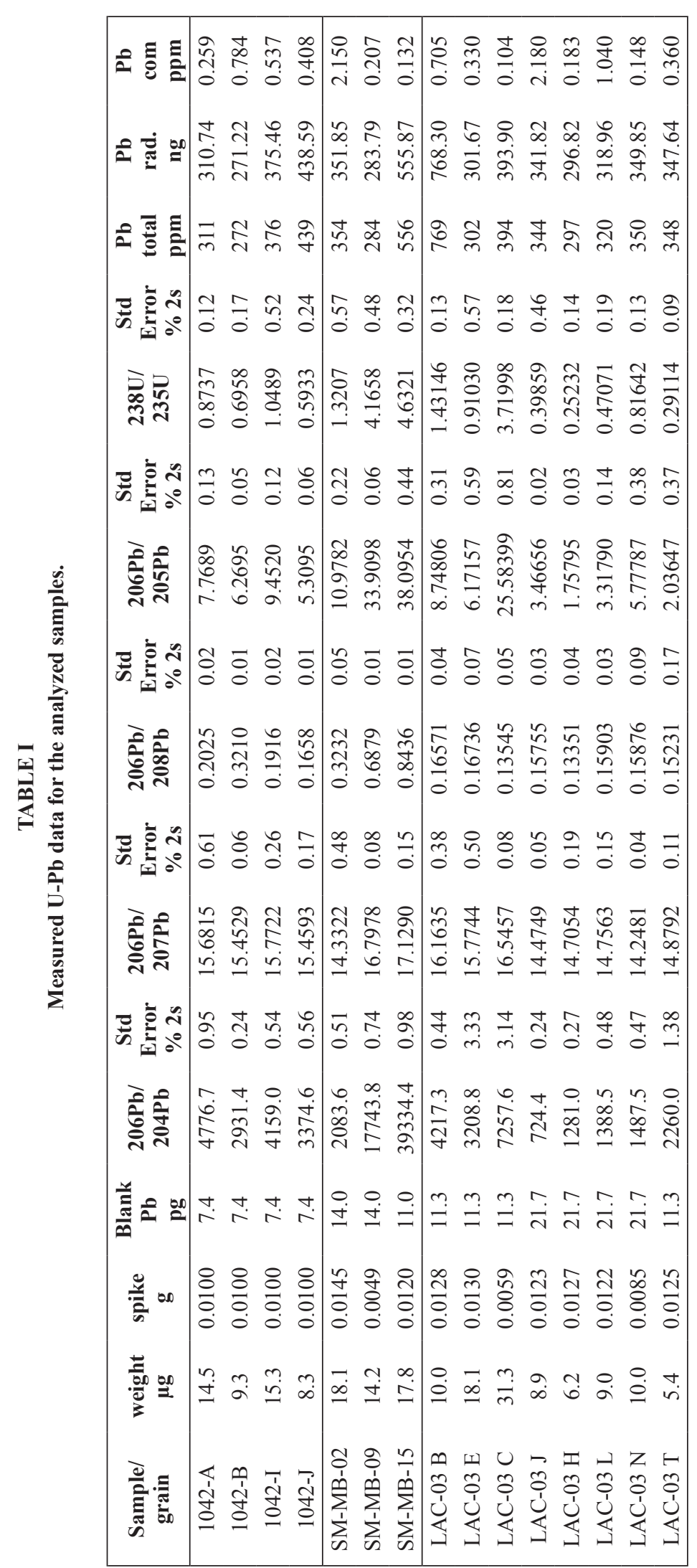




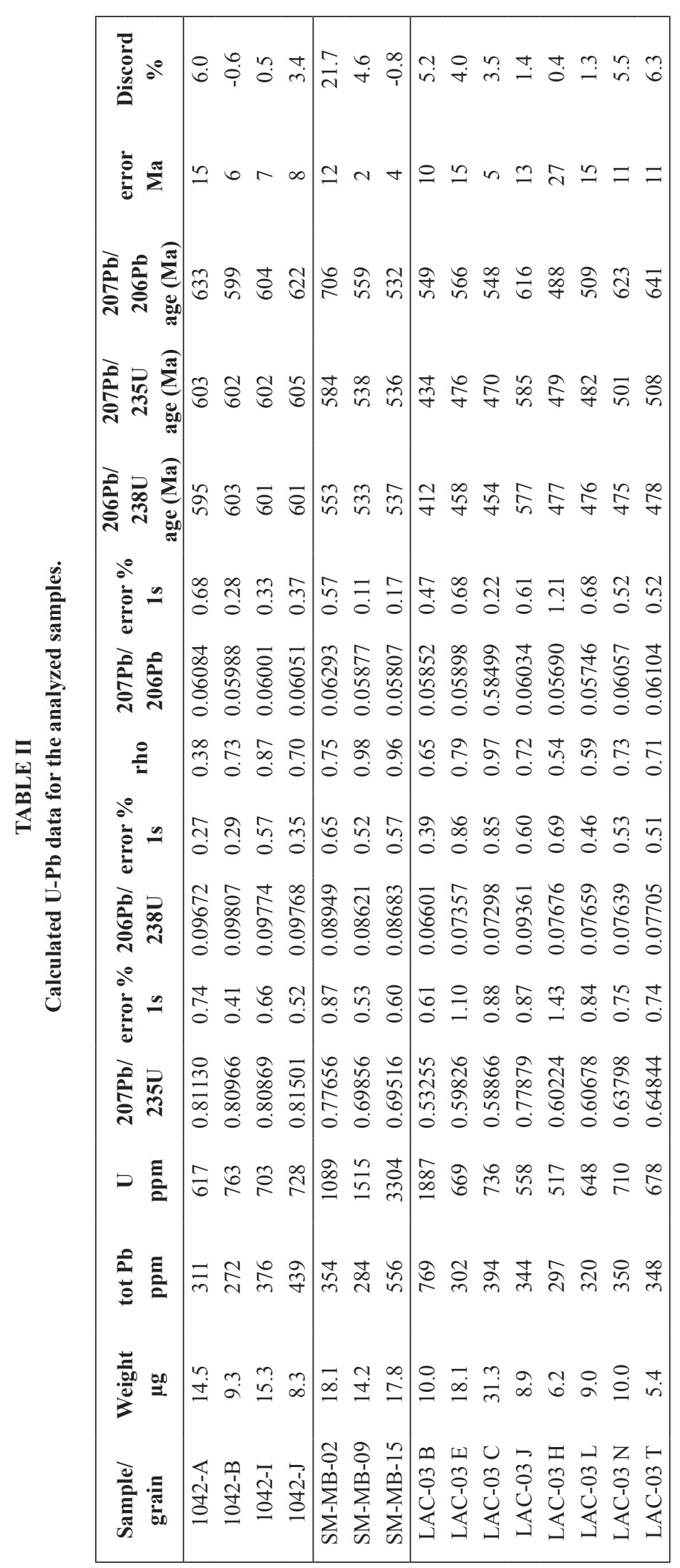


The only older grain $\mathrm{J}$, yielded $\mathrm{a}^{206} \mathrm{~Pb} /{ }^{238} \mathrm{U}$ age of $577 \mathrm{Ma}$ (Figure 6c), which is broadly coincident with the main regional M1 metamorphic episode of the central Ribeira belt (Machado et al. 1996). Three other discordant grains (B, C, E), along with the latter $(\mathrm{J})$ grain, define a discordia line with an upper intercept of $628 \pm 68 \mathrm{Ma}$ (Figure 6d), which point to the age range of the pre-collisional granitoid rocks of the Rio Negro Magmatic Arc (Tupinambá et al. 2011).

\section{CONCLUSIONS}

A wide variety of analytical protocols were installed, including those directly and indirectly related to the actual analysis of a sample. Among the former are weighing, cleaning and digestion of selected grain, chemical extraction of $\mathrm{Pb}$ and $\mathrm{U}$, loading onto filaments and mass spectrometric analysis. Among the latter procedures are the purification of acids and water, cleaning of used vessels and vials, preparation and calibration of solutions, determination of reagent and total blanks, calibration of ion exchange columns for the extraction of $\mathrm{Pb}$ and $\mathrm{U}$, establishment of mass fractionation, cup configuration and other mass spectrometry parameters, and analysis of reference materials.

The cleanliness of the facilities, lab ware and chemical procedures in LAGIR is expressed by the low levels of $\mathrm{Pb}$ blanks in reagents, $\sim 0.5 \mathrm{pg} / \mathrm{g}$ in acids and $\sim 1 \mathrm{pg} / \mathrm{g}$ in $\mathrm{H}_{2} \mathrm{O}$, and below $22 \mathrm{pg} \mathrm{Pb}$ for the total chemical procedure.

However subjected by the restrictions of having used whole monazite grains, and regardless of any degree of internal heterogeneity, the preliminary results presented here are geologically meaningful. The new data either exactly matches pre-existing ones, as was in the case of the Araxá Group (1042) quartzite sample, or they make geological sense when integrated to the geochronology database of regional tectonic processes related to the formation of the Gondwana supercontinent.
Better precision and accuracy in the future is expected with improving spatial resolution either through micro-drilling or progressive leaching techniques.

\section{ACKNOWLEDGMENTS}

The authors thank the late Nuno Machado (GEOTOP-UQAM, Montréal), who back in year 2000 planted the seeds of LAGIR. This work was only possible with the 205-235 tracer that was shared by the staff from the Geochronology lab at the University of Brasília. This tracer was originally prepared by W.R. Van Schmus (Univ. Kansas), who blessed us with his cool ways and expertise. W. Sproesser (Univ. São Paulo) and the Geochemistry Lab of FGEL-UERJ instrumental. Conselho Nacional de Desenvolvimento Científico e Tecnológico (CNPq), Financiadora de Estudos e Projetos (FINEP) and Fundação Carlos Chagas Filho de Amparo à Pesquisa do Estado do Rio de Janeiro (FAPERJ) funding agencies helped LAGIR keep working. An anonymous reviewer of an earlier version of the manuscript, and suggestions by Annette Victor on English writing are acknowledged.

\section{RESUMO}

Procedimentos químicos e espectrométricos do método geocronológico $\mathrm{U}-\mathrm{Pb}$ em monazita, recentemente instalado no Laboratório LAGIR, são descritos em detalhe. Adicionalmente, resultados preliminares de amostras de monazita das faixas Brasília e Ribeira são relatados e discutidos no contexto geológico regional. Vários experimentos de calibração de colunas de troca iônica com resina $\mathrm{AG}-1 \mathrm{x} 8$ foram realizados com $\mathrm{HCl}$, usando amostras de monazita naturais dissolvidas. Os brancos de $\mathrm{Pb}$ dos reagentes são $\sim 0,5 \mathrm{pg} / \mathrm{g}$ em ácidos e $\sim 1 \mathrm{pg} / \mathrm{g}$ em $\mathrm{H}_{2} \mathrm{O}$. Os brancos de $\mathrm{Pb}$ nos procedimentos químicos foram inferiores a $22 \mathrm{pg}$. Os resultados preliminares são apresentados nos três estudos de casos relatados em faixas orogênicas Brasilianas da região SE do Brasil, que se correlacionam muito bem com determinações prévias 
de idade da literatura: dois grãos subconcordantes de um quartzito do Grupo Araxá (faixa Brasília meridional) definem uma idade concórdia de 602,6 \pm 1,4 Ma; Um grão $-0,8 \%$ discordante de um quartzito do Grupo São Fidelis (Domínio Costeiro, Faixa Ribeira central) forneceu uma idade concórdia de 535,3 $\pm 2,4 \mathrm{Ma}$; dois grãos de monazita $0,4 \%$ e $1,3 \%$ discordantes do Granito poscolisional Itaoca (Domínio Costeiro, faixa Ribeira central) definem uma idade concórdia de 476,4 \pm 1,8 Ma.

Palavras-chave: Gondwana, Brasiliano, espectrometria de massas por diluição isotópica, U-Pb, monazita.

\section{REFERENCES}

Basei MAS, Siga Junior O, SAto K and Sproesser WM. 1995. A Metodologia Urânio-Chumbo na Universidade de São Paulo. Princípios Metodológicos, Aplicações e Resultados Obtidos. An Acad Bras Cienc 67: 221-237.

Buhn B, Pimentel MM, Matteini M And Dantas EL. 2009. High spatial resolution analysis of $\mathrm{Pb}$ and $\mathrm{U}$ isotopes for geochronology by laser ablation multi-collector inductively coupled plasma mass spectrometry (LA-MC-ICPMS). An Acad Bras Cienc 81: 99-114.

Chemale JR F, KaWAshita K, Dussin IA, Ávila JN, Justino D AND BERTOTTI A. 2012. U-Pb zircon in situ dating with LA-MC-ICP-MS using a mixed detector configuration. An Acad Bras Cienc 84: 275-295.

Cordani UG, Brito-Neves BB AND D'Agrella MS. 2003. From Rodinia to Gondwana: a review of the available evidence from South America. Gondwana Res 6: 275-284.

DARDENNE MA. 2000. The Brasília fold belt. In: Cordani UG et al. (Eds), Tectonic Evolution of South America. $31^{\text {st }}$ International Geological Congress, Rio de Janeiro, p. 231-263.

DEER WA, HowIE RA AND ZUSSMAN Y. 1966. An introduction to the rock forming minerals. $2^{\text {nd }}$ ed., London: Longman, $727 \mathrm{p}$.

DICKIN A. 1995. Radiogenic Isotope Geology. UK: Cambridge University Press, $452 \mathrm{p}$.

Foster G, Gibson HD, PARrish RR, HORSTwOOd M, Fraser J AND TINDLE A. 2002. Textural, chemical and isotopic insights into the nature and behaviour of metamorphic monazite. Chem Geol 191: 183-207.

Fuck RA, Brito NeVEs BB AND SchobBenhaus C. 2008. Rodinia descendants in South America. Precambrian Res 160: 108-126.

HAWKINS DP AND BowRING SA. 1997. U-Pb systematics of monazite and xenotime: case studies from the Paleoproterozoic of the Grand Canyon. Arizona. Contr Miner Petrol 127: 87-103.

HEAMAN L AND PARRISH R. 1990. U-Pb geochronology of accessory minerals. Short course handbook on applications of radiogenic isotope systems to problems in geology. Mineralogical Association of Canada 19: 59-102.
HeILBRon M. 2012. Geologia e Recursos Minerais da Folha Santo Antônio de Pádua - SF.26-X-D-VI. $1^{\text {a }}$ ed., Belo Horizonte: CPRM, p. 1-21.

HEILBRON M AND MACHADO N. 2003. Timing of terrane accretion in the Neoproterozoic Eo-Paleozoic Ribeira orogen (SE Brazil). Precambrian Res 125: 87-112.

HeIlbron M, Mohriak WU, Valeriano CM, Milani E, ALMEIDA JCH AND TUPINAMBÁ M. 2000. From collision to extension: the roots of the south-eastern continental margin of Brazil. In: Talwani $M$ and Mohriak WU (Eds), Atlantic Rifts and Continental Margins. American Geophysical Union, Geoph Monog 115: 1-34.

HeILbron M, SoARes ACP, CAMpos N, Silva LC, Trouw RAJ AND JANASI V. 2004. Província Mantiqueira. In: MantessoNeto V, Bartorelli A, Carneiro CDR and Brito-Neves BB (Orgs), Geologia do Continente Sul Americano: Evolução da Obra de Fernando Flávio Marques de Almeida. São Paulo, p. 203-234.

Heilbron M, VAleriano CM, TAssinari CCG, Almeida JCH, TupinambÁ M, SigA O AND Trouw RAJ. 2008. Correlation of Neoproterozoic terranes between the Ribeira Belt, SE Brazil and its African counterpart: comparative tectonic evolution and open questions. Geol Soc Special Publication 294: 211-237.

LUDWIG KR. 1993. PBDAT. A computer program for processing $\mathrm{Pb}-\mathrm{U}-\mathrm{Th}$ isotope data. USGS Open File Report 88-542, 34 p.

LUDWIG KR. 2003. User's manual for Isoplot 3.00: a geochronological toolkit for Microsoft Excel. Berkeley Geochron Center Special Publication 4: 70.

MaChado N, VALLADARES CS, HeILBRON M AND VALERIANO CM. 1996. U-Pb geochronology of Central Ribeira belt. Precambrian Res 79: 347-361.

Mantovani MSM AND BRITo Neves BB 2005. The Paranapanema lithospheric block: its importance for Proterozoic (Rodinia, Gondwana) supercontinent theories. Gondwana Res 8: 303-315.

Neto CCA, VAleriano CM, VAZ GS AND RAGATKy CD. 2012. Monazite U-Pb (ID-TIMS) age of post-collisional Itaoca Granite, central Ribeira Belt, Rio de Janeiro State, Brazil. South American Symposium on Isotope Geology, Medellin, Colombia (CD-ROM).

PARRISH RR. 1990. U-Pb dating of monazite and its application to geological problems. Can J Earth Sci 27: 1431-1450.

PARRISH RR AND KROGH TE. 1987. Synthesis and purification of ${ }^{205} \mathrm{~Pb}$ for $\mathrm{U}-\mathrm{Pb}$ geochronology. Chemical Geology: Isotope Geoscience Section 66: 103-110.

PASSARElli CR, BASEI MAS, Siga JúNIOR O, SATO K AND LoIOS VAP. 2009. Dating minerals by ID TIMS geochronology at times of in situ analyses: selected case studies from CPGeo IGc - USP. An Acad Bras Cienc 81: 1-25.

SATO K, BASEI MAS, TASSINARI CCG AND Siga JUNIOR O. 2008b. Multi Collector SHRIMP IIe of Brazil. In: $4^{\text {th }}$ International SHRIMP Workshop, Saint-Petersburg, Russia. Abstracts Volume, p. 106-108. 
SATO K, BASEI MAS, Siga JR O, Sproesser WM AND PASSARELLI CR. 2008a. Novas técnicas aplicadas ao método U-Pb no CPGeo - IGc/USP: avanços na digestão química, espectrometria de massa (TIMS) e exemplos de aplicação integrada com SHRIMP Geologia USP: Série Científica 8(2): 77-99.

SCHMITT RS, TROUW RAJ, VAN SCHMUS WR AND PIMENTEL MM. 2004. Late amalgamation in the central part of Western Gondwana: new geochronological data and the characterization of a Cambrian collision orogeny in the Ribeira Belt (SE Brazil). Precambrian Res 133: 29-61.

TERA F AND WASSERBURG GJ. 1972. U-Th-Pb systematics in therr Apollo 14 basalts and the problem of initial $\mathrm{Pb}$ in lunar rocks. Earth Planet Sci Lett 14: 281-304.

TUPINAMBÁ M, HEILBRON M, VALERIANO CM, PORTO JUNIOR R, Dios FRB, Machado N, Silva LGE and Almeida JCH. 2011. Juvenile contribution of the Neoproterozoic Rio Negro Magmatic Arc (Ribeira Belt, Brazil): Implications for Western Gondwana amalgamation. Gondwana Res 21: 422-438.

TUPINAmBÁ M, TEIXEIRA W AND HeILBRON M. 2000 Neoproterozoic Western Gondwana assembly and subduction-related plutonism, the role of the Rio Negro complex in the Ribeira belt, south-eastern Brazil. Rev Bras Geociênc 30: 7-11.

VALERIANO CM ET AL. 2003. A new TIMS laboratory under construction in Rio de Janeiro, Brazil. In: IV South American Simposium on Isotope Geology, Salvador. Short Papers IV South American Symposium on Isotope Geology. Salvador 1: 131-133.
VALERIANo CM, Machado N, SimonetTi A, VAlladares CS, SEER HJ AND SIMÕES LSA. 2004. U-Pb geochronology of the southern Brasília belt (SE-Brazil): sedimentary provenance, Neoproterozoic orogeny and assembly of West Gondwana. Precambrian Res 130: 27-55.

VALERIANO CM, PIMENTEL MM, HEILBRON M, ALMEIDA JCH AND TROUw RAJ. 2008. Tectonic evolution of the Brasília Belt, Central Brazil, and early assembly of Gondwana. Geol Soc Special Publication 294: 197-210.

Valeriano CM, Simões LSA, Teixeira W and HeILBRon M. 2000. Southern Brasília belt (SE Brazil): tectonic discontinuities, $\mathrm{K}-\mathrm{Ar}$ data and evolution during the Neoproterozoic Brasiliano orogeny. Rev Bras Geociênc 30: 295-299.

VALERIANo CM, TupinambÁ M, SimonetTi A, HeILbron M, ALMEIDA JCH AND EIRADO LG. 2011. U-Pb LA-MCICPMS geochronology of Cambro-Ordovician postcollisional granites of the Ribeira belt, southeast Brazil: Terminal Brasiliano magmatism in central Gondwana supercontinent. J S Am Earth Sci 32: 416-428.

VLACH SRF. 2010. Th-U-Pb dating by the Electron Probe Microanalysis, Part I. Monazite: analytical procedures and data treatment. Geologia USP: Série Científica 10: 61-85.

WILLIAMS ML, JERCINOVIC MJ AND HETHERINGTON CJ. 2007. Microprobe monazite geochronology: Understanding geologic processes by integrating composition and chronology. Annu Rev Earth Planet Sci 35: 137-175. 